\title{
HYDROGELS BASED ON N-ISOPROPYLMETHACRYLAMIDE AND $N$-ISOPROPYLACRYLAMIDE
}

Maja Z. Urošević1 ${ }^{*}$, Ljubiša B. Nikolić ${ }^{1}$, Snežana S. Ilić-Stojanović1, Vesna D. Nikolić ${ }^{1}$, Sanja M. Petrović ${ }^{1}$, Aleksandar S. Zdravković ${ }^{2}$

(REVIEW PAPER) UDC 544.773.432:678.7:615.015.3

${ }^{1}$ University of Niš, Faculty of Technology, Leskovac, Serbia

${ }^{2}$ Vocational High School for Technology and Art, Leskovac, Serbia

Hydrogels are three-dimensional polymer networks which have the capacity to retain a large quantity of water or biological fluids in the swollen state. Thermosensitive hydrogels have received special attention of reserachers since they represent a parameter which frequently changes in chemical, biological and physiological systems. Thermosensitive hydrogels have the critical solution temperature, i.e. they exhibit a substantial change in volume with the temperature change. Homopolymers poly $(N$-isopropylmethacrylamide) (poly(NIPMAM)) and poly ( $N$-isopropylacrylamide) (poly(NIPAM)) are thermosensitive materials which have lately become the subject of intensive study. Monomer $\mathrm{N}$-isopropylmethacrylamide, NIPMAM, enters into copolymerization with monomer $N$-isopropylacrylamide, NIPAM, in order to create a system with a phase transition temperature approximate to the human body temperature. In literature data there is available information on the synthesis and characterization of microgels, nanogels and copolymers based on NIPMAM and NIPAM. These thermosensitive polymer materials are used in controlled drug delivery and protein immobilization.

\section{Introduction}

Hydrogels are three-dimensional polymer networks made from natural or synthetic materials which can absorb large amounts of water due to their high degree of flexibility $[1,2]$. An important characteristic of hydrogels is the fact that they do not dissolve but swell in water and water solutions [3]. They resemble biological tissues because of the high content of water, their softness and biocompatibility [1,2]. They are also called 'smart' networks and are the subject of scienitific research because of the potential for high-tech application in the field of biomedicine, pharmacy, biotechnology, bioseparation, biosensors, agriculture and cosmetics. The history of smart hydrogels dates back to 1960 [4]. Smart hydrogels exhibit significant physical and chemical changes in response to slight changes in their environment [5]. These also belong to the group of hydrogels which are sensitive to external stimuli [6]. These materials can synthesize in response to a number of physiological stimuli present in organism, such as $\mathrm{pH}$, ionic strength and temperature [2]. By varying these, the material properties such as a degree of swelling, porosity, a physical structure, etc. can be affected [6]. The arising changes are reversible. Therefore, hydrogels can return to their original state after removing the environmental stimuli [5]. Natural and synthetic polymers can be used for the synthesis of hydrogels [7]. Although synthetic hydrogels do not have distinctive properties as the natural ones (biodegradability, biocompatibility etc), their structure enables them to acquire these properties through modification.
The choice of monomers in the synthesis of polymer hydrogels is of high significance, as it affects the chemical structure and subsequently the properties of hydrogels [7-9]. In the last decade, big attention of reserachers has been drawn by thermosensitive hydrogels [10]. The polymers that change their properties under slight changes in temperature are used in the synthesis of thermosensitive hydrogels [11]. Depending on the temperature of the surrounding fluid, they swell or contract $[12,13]$. This behaviour can be used to develop the so called 'smart' drug delivery systems that mimic biological behaviour to a certain extent [11]. The key process for the application of thermosensitive hydrogels in drug delivery is the critical solution temperature $[14,15]$. Polymers with the low critical solution temperature (LCST) swell below and contract above the LCST, which is used as a mechanism for the drug release [14]. They represent excellent systems for delivery of hydrophilic and hydrophobic drugs, as well as small and large, polar and non-polar, stable and unstable molecules [10]. Significant progress, particularly in the field of tissue engineering, has been made by using hydrogels that belong to this class [12]. These hydrogels are interesting for biomedical purposes, since they are able to swell in situ under physiological conditions and ensure an advantage compared to the ordinary use [13]. Poly $(N$ isopropylacrylamide), poly(NIPAM), and their copolymers with other synthetic or natural polymers are one of the

\footnotetext{
*Author address: Maja Urošević, University of Niš, Faculty of Technology,

Bulevar Oslobođenja 124, 16000 Leskovac, Serbia

E-mail: maja91mail@gmail.com

The manuscript received: January, 09, 2018.

Paper accepted: April, 04, 2018.
} 
most important tested thermosensitive systems [13]. Thermosensitive copolymer based on $N$-isopropylmethacrylamide (NIPMAM) and $N$-isopropylacrylamide (NIPAM) is a special focus of interest. Due to the presence of two similar thermosensitive structures, this copolymer exhibits a sharp phase transition under physiological conditions $(\mathrm{pH}$ 7.4 phosphate buffer solution), which makes it appropriate for biomedical use [16]. In the study of Funueanu et al., a micrometric-sized poly( $N$-isopropylmethacrylamide-co- $N$ isopropylacrylamide), poly(NIPMAM-co-NIPAM), hydrogel was synthesized, which was used as a system for a pulsatile drug release [16].

The aim of this study is to review the procedures for the synthesis of hydrogels based on NIPMAM and NIPAM, their characterization and potential use as delivery and immobilizing systems.

Poly(N-isopropylmethacrylamide), poly(NIPMAM)

Poly( $N$-isopropylmethacrylamide), poly(NIPMAM), belongs to the group of thermosensitive polymers [17-19]. It has one additional methyl group on each monomer unit compared to poly(NIPAM) [20]. The additional methyl group has an impact on the intrachain collapse and interchain association [21]. Due to the steric hindrance of the methyl group, hydrophobic residues cannot interlink, which results in a phase transition at a higher temperature $[16,22]$. The phase transition of poly(NIPMAM) aqueous solutions is within the temperature range of $38-42{ }^{\circ} \mathrm{C}$ [23]. Compared to poly(NIPAM) chains, poly(NIPMAM) chains form less stable aggregate during the phase transition. Poly(NIPMAM) chains can become almost dehydrated at the temperatures higher than LCST [20]. Figure 1 shows the chemical structure of poly(NIPMAM).

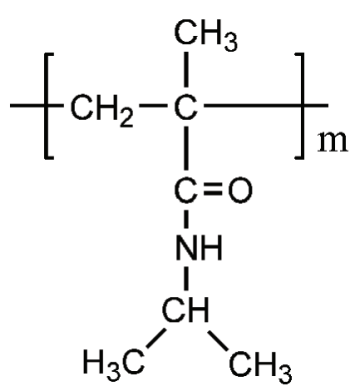

Figure 1. The chemical structure of poly(NIPMAM) homopolymer

Since the critical solution temperature is the basic feature of thermosensitive polymers, it has been studied from various aspects by a large number of researchers of poly(NIPMAM).

The quantitative or semi-quantitative study of reversibility of the temperature induced by the change of hydratation was used in the study of Zhang et al. The hydratation change in poly(NIPMAM) indicates significant irreversibility during the process of the phase separation [24]. Through the quantitative comparison of reversibility in the temperature induced poly(NIPMAM) and
poly(NIPAM) hydration in aqueous solutions by 2D correlation analysis, Yhang Wu et al. demonstrated that hydratation of hydrophylic amide group has a major impact on the temperature-induced phase separation of polymers in an aqueous solution [25].

In the study of Kirsh et al. on poly(NIPMAM) and poly( $N$-vinylcaprolactam), poly(VCL), were subjected to the reversible phase separation in water, as a function of temperature. The phase separation was studied in aqueous solutions of these polymers as a function of the concentration of the dissolved substance and structure. The poly(NIPMAM) temperature behaviour is not responsive to the structure of the dissolved substance [26]. The temperature-induced phase separation of poly(NIPMAM) homopolymer or other homopolymers in various mixtures of solvents was studied by the method of nuclear magnetic resonance, NMR [27-34].

Tang and associates have studied the association and dissociation of poly(NIPMAM) chains in water. The research has shown that poly(NIPMAM) chains form larger aggregates at the temperature above their LCST and undergo a change in enthalpy and entropy smaller than in poly(NIPAM) chains during phase transition, which indicates that poly(NIPMAM) chains have less conformational changes [20].

In the study of Salmerón Sánchez et al. poly(NIPMAM) thermal transitions in aqueous solutions have been examined under a wide temperature range between $60{ }^{\circ} \mathrm{C}$ and $100^{\circ} \mathrm{C}$ by applying differential scanning calorimetry (DSC). Various mass polymer fractions were analyzed $(c=0.03-1)$. The presence or absence of the temperature-induced phase transition was explained. The temperature-induced transition is related to the role which hydrophobic parts of polymer chains have, thus leading to the macroscopic separation of phases at a characteristic temperature. The disappearance of the temperatureinduced phase transition at a specific concentration of polymers in the solution can be explained by glass transition, which indicates the presence of non-crystalized water in the solution [34]. Habaue et al. studied stereoregularity of radical polymerization of acrylamide (AM) and methacrylamide (MAM) by using Lewis' acids. The variety in stereoregularity of obtained polymers had a distinctive effect on the phase transition of poly(NIPMAM) in water induced by temperature [36]. In their paper, Dybal et al. compared the temperature which induces the phase transition in the aqueous solution of poly(NIPAM) and poly(NIPMAM) by using attenuated total reflectionFourier transform infrared spectroscopy (ATR-FTIR) and Raman spectroscopy combined with quantum chemical calculations. The findings of the study indicated that presence or absence of a-methyl group has a strong effect on the physical structure of aqueous solutions. Although hydrophobic interactions of poly(NIPAM) and poly(NIPMAM) are very similar, poly(NIPMAM) with an additional methyl group demonstrates significantly weaker intra-molecular interactions between the amide group. That effect causes the transition temperature to be about 
$8^{\circ} \mathrm{C}$ higher for poly(NIPMAM) compared to poly(NIPAM), due to the formation of larger compact structures [37].

Compared to poly(NIPAM), the phase transition in poly(NIPMAM) aqueous solution has been less analyzed $[23,38,39]$. Although poly(NIPMAM) has a high LCST value, the phase transition is very sharp, thus making it an adequate monomer for copolymerization [16]. On the basis of experimental findings on swelling of copolymer gels poly( $\mathrm{N}$-isopropylacrylamide-Co-acrylic acid), poly( $N$-isopropylacrylamide-co-itaconic acid), poly( $N$-isopropylmethacrylamide-co-sodium acrylic acid) and poly $(\mathrm{N}$-isopropylmethacrylamide-co-sodium methacrylate) in controlled and uncontrolled conditions, Drosdov et al. developed a model for mechanical and water absorption behaviour in temperature and $\mathrm{pH}$ sensitive gels [40]. In literature, synthetic poly(NIPMAM) microgels have been synthesized in addition to the classical ones. In the paper of Wedel et al., the properties of smart homopolymer microgels have been compared: $\operatorname{poly}(N-$ $n$-propyl acrylamide), poly(NNPAM), poly(NIPAM) and poly(NIPMAM) synthesized through conventional surfactant-free precipitation polymerization. By using scanning electronic microscopy (SEM) and atomic force microscopy (AFM), the size, morphology and degree of swelling in microgels have been analyzed. Poly(NIPAM) microgels exhibit a very sharp volume phase transition, whereas poly(NIPMAM) particles have been found to exhibit a more homogenous network structure compared to the other two systems [41]. Since controlling of sizes is one of the most important tasks during the synthesis of coloids, Nessen et al. used anionic surfactant sodium dodecyl sulfate (SDS) and cationic surfactant cetyl trimethylammonium bromide (CTAB) for the accurate control of the sizes of poly(NIPMAM) microgel particles prepared through precipitation polymerization. The concentration of the surfactant varied in a wide range under the critical miscelle concentration (CMC). The size of the obtained particles, size distribution and shape were studied by electronic scanning microscopy and atomic force microscopy. The photon correlation spectroscopy was used in the analysis of the volume phase transition of microgels. The findings in the study show that the increase in concentration of both surfactants causes the decrease in the size of particles, thus making the swelling properties of microgels almost unchanged [42]. The coloide, physical and chemical properties of cross-linked poly(NIPMAM) latex polymers have been studied by Duracher et al. The research shows that the diameter of a particle reduces with a rise in temperature, thus confirming the thermosensitivity of poly(NIPMAM) particles. A significant impact of the polymerization temperature and the initiator concentration on LCST has been noticed. The average LCST for cross-linked poly(NIPMAM) latex polymer is about $43{ }^{\circ} \mathrm{C}$ [43]. Alenichev et al. have studied swelling and mechanical behavior of positively and negatively charged poly(NIPMAM) and poly(NIPAM) network in the mixture of water/ethanol, at the room temperature [44]. The research has shown that there is a strong effect of cononsolvency in non-charged and negatively charged gels in both systems, whereas high and minimal degree of swelling has been noticed in pure solvents and solvent mixtures, respectively. On the other hand, the positively charged networks in both systems exhibit approximately constant values in the swelling degree regardless of the composition of the solvent mixture [44]. The kinetics of coil-to-globule transition of poly(NIPMAM) linear chains was studied by using fluorescence and Rayleigh scattering with a fast laser pulse infrared heating by Tang and Liu. The coil-to-globule transition of poly(NIPMAM) is similar to the one in poly(NIPAM), indicating that the additional methyl group in poly(NIPMAM) chains has a slight impact on kinetics [21]. The impact of $\alpha$-methyl substitution on the formation of interpolymer complexes between poly(NIPAM) and poly(acrylic acid), poly(AA), poly(NIPAM) and poly(methacrylic acid), poly(MAA), poly(NIPMAM) and poly(AA), poly(NIPMAM) and poly(MAA) and their properties have been studied by Ruiz-Rubio et al. The research shows that poly(NIPMAM)-co-poly(MAA) has the highest thermal stability. Therefore, $\alpha$ methylation in both polymer components accounts for not only high glass transition at a temperature above $200{ }^{\circ} \mathrm{C}$, but also for avoidance of the anhydration process i.e. a delay in material degradation [45].

Poly(N-isopropylacrylamide), poly(NIPAM)

Poly(NIPAM) is well-known as a typically thermosensitive polymer. Homopolymer poly(NIPAM) and other AM-based polymers which are amphiphilic in nature, exhibits LCST in aqueous solutions. These polymers swell at the lowest temperatures, whereas heating above LCST causes contraction due to expelling of water [4648]. Abrupt macromolecular transition in poly(NIPAM) from hydrophilic to hydrophobic structure occurs as a consequence of LCST [47]. Poly(NIPAM) aqueous solutions have LCST at approximately $32{ }^{\circ} \mathrm{C}$ [49-53]. The chemical structure of poly(NIPAM) is shown in Figure 2.<smiles>CC(C)NC(=O)C(CC(C)(C)C)C(C)(C)C</smiles>

Figure 2. The chemical structure of poly(NIPAM) homopolymer

The research of Kureačič et al. is focused on identifying the mechanism of polymerization and cross-linking of poly(NIPAM) hydrogels and their swelling properties. Hydrogels were synthesized through an environmentally-friendly procedure of UV polymerization from the NIPAM monomers and various concentrations of $N, N^{\prime}-$ 
methylenebisacrylamide, BIS, as a cross-linker. The results show that the concentration of cross-linkers affects the hydrogel structure and swelling properties. Through an increase in the concentration of a cross-linker, the hydrogel structure changes from homogeneous into heterogeneous with a decrease in the equilibrium swelling degree [54]. Copolymer poly( $N$-isopropylacrylamide-co2-hydroxypropyl methacrylate), poly(NIPAM-co-HPMet), is one of the examples of negatively thermosensitive hydrogels $[8,9]$. Superabsorbent hydrogels are gels with the capacity of absorbing 100 times higher than the xerogel weight [55]. Hydrogels with superabsorbent properties are synthesized through radical polymerization from the NIPAM and AA monomers, as presented in the paper of Zdravković et al. poly(NIPAM-co-AA) hydrogels demonstrate $\mathrm{pH}$ sensitivity whereupon the equilibrium swelling degree increases from 8.3 to 259.8 with the rise in $\mathrm{pH}$ values from 2.2 to 6.8 [56]. The absorption capacity of hydrogels can be used for concentrating solutions of different compounds, i.e. for separation of these from aqueous solutions $[57,58]$. NIPAM-based hydrogels and anionic comonomers are used for the removal of pollutants with the aim of the environmental protection [59-61]. Optical humidity sensors are made from poly(NIPAM-coAA) microgels in the study of Islam et al. [62]. The devices are constructed by initially depositing a monolite layer of poly(NIPAM-co-AA) microgels on Au-coated glass substrates and subsequently by depositing another Au layer on the top. It has been found that the thickness of the microgel layer is dependent on air humidity, thus corresponding to the change in optical properties of the device. A microgel contracts at a very low level of humidity, whereas it swells with the increase. In addition, hygroscopic polymer poly(diallyldimethylammonium chloride), poly(DADMAC), which deposits on the microgel layers and its impact on the device sensitivity was also examined. It was found that the device sensitivity to humidity increases with the increase in the number of layers poly(DADMAC) [62]. Poly(NIPAM) was used for absorption of $\mathrm{Pb}^{2+}$ ion at the temperatures below LCST homopolymer in the study of Yu et al. [63]. Hydrogels containing amino and amide groups can be used for the adsorption of heavy metals [64]. In the study of Chen et al., poly(NIPAM-co-AA) hydrogel was used for removing $\mathrm{Cu}^{2+}$ ions. It was found that at a lower temperature $\left(<40{ }^{\circ} \mathrm{C}\right)$, the retention of $\mathrm{Cu}^{2+}$ ion is much more common compared to a higher operating temperature. The adsorption of $\mathrm{Cu}^{2+}$ ion on poly(NIPAM-co-AA) hydrogel depends on the temperature and $\mathrm{pH}$ value of the surrounding medium [65].

The composite hydrogels poly( $N$-isopropylacrylamide-co-acrylamide)-co-polyethylene glycol-co-Phosphotungstic acid were synthesized at $70{ }^{\circ} \mathrm{C}$ through copolymerization of NIPAM and AM in the presence of polyethylene glycol (PEG) by using potassium persulfate (KPS) as an initiator. BIS and phosphotungstic acid (PTA) were used as chemical and physical cross-linkers, respectively. The hydrogels showed the upper critical solution temperature (UCST), $59.6{ }^{\circ} \mathrm{C}$. The research contributed to the easier identification of the phase transition and new insight into the synthesis of sensitive hydrogels [66]. The mechanical properties of external stimuli-responsive hydrogels are of key importance for their various applications. Interpenetrating polymer networks (IPN), double network (DN), nanocomposites (NC) were analyzed in the study of Haq et al. with the aim to improve mechanical properties of poly(NIPAM) hydrogels [67]. The contraction of IPN hydrogels of thermosensitive poly(NIPAM) and hydrophilic poly(AM) was examined by combining NMR spectroscopy, the small angle neutron scattering (SANS) method and the DSC method. The effect of the preparation and composition of IPNs on the phase transition was studied for the purpose of application of these sensitive materials for drugs delivery and molecular separation [68].

The two types of poly(MAA)-co-poly(NIPAM) microgels with $\mathrm{pH}$ sensitive poly(MAA) core and thermosensitive poly(NIPAM) shell were prepared through distillation precipitation or emulsion precipitation copolymerization of NIPAM and BIS in the presence of poly(MAA) microgel core. Due to a different poly(MAA) core and poly(NIPAM) shell swelling degree in acetonitrile and water, poly(MAA)-co-poly(NIPAM) microgels demonstrate a various rate of change in the volume depending on the external stimuli. The effect of drug incorporation and its controlled release were studied. Doxorubicin was used as a model substance [69]. Thermosensitive poly(NIPAM) hydrogel was used as a model for the preparation of monodisperse, milimeter- or submilimeter-sized polymer hydrogel beads in compliance with a new manufacturing method which combines sediment polymerization and electrostatic spraying. The size of droplets generated on the top of the nozzle corresponds to the size of obtained hydrogel beads, which is controlled by adjusting the voltage applied. Monodisperse, millimeter- or submilimeter-sized poly(NIPAM) hydrogel beads were successfully prepared by applying the new procedure [70]. In the study of Palomino et al., hydrogels with various ratios of poly(NIPAM) microparticles were examined. Microstructured hydrogels with a small quantity of microparticles enable a positive control of the drug release i.e. the controlled pulsatile drug release. The optimal mechanical properties of poly(NIPAM) hydrogels were achieved at a small content of microparticles. The degree of cross-linking has little effect compared to the ratio of microparticles in swelling and the drug release as response to temperature [71]. Poly(NIPAM) based hydrogels are one of the most common thermosensitive polymers applied in the drug delivery systems. They interact easily with small aromatic molecules. The nature and strength of interactions have an impact on the efficiency and kinetics of the drug release. Fenols have a major impact on poly(NIPAM) by decreasing its phase transition temperature. The impact shows linear dependence on the fenol concentration, the number of fenol $\mathrm{OH}$ groups, as well as its relative positions. Derivatives of do- 
pamine and amino fenols increase the phase transition temperature. Strong interactions between the molecules of dopamine are favorized, thus hindering the reactions of polymer-dopamin and leading to the crystallization of dopamine upon the removal of water. These findings show that the incorporation of a drug in polymer matrices for controlled drug delivery can alter the crystallinity of a drug molecule. Morphology is the key factor in the drug release; therefore, it can hinder the rate and efficiency in the drug release [72]. Constantin et al. synthesized $\mathrm{pH}$ and thermosensitive porous hydrogels based on NIPAM and MAA as self-regulating systems for drug delivery [73]. The thermosensitive micelle complex made up from biocompatible grafted copolymer sodium alginate-graftpoly( $N$-isopropylacrylamide) (SA-g-poly(NIPAM)) and two-valent ion of metal was prepared for the controlled drug release. The structure of micelles is made up from metal ions $\left(\mathrm{Ba}^{2+}, \mathrm{Zn}^{2+}, \mathrm{Co}^{2+}\right)$, cross-linked sodium alginate and thermosensitive poly(NIPAM). The polymer micelle demonstrated good polydispersivity and excellent performance for incapsullation and the drug release. The superior metal-induced properties of sensitive polymer micelles indicate their application in controlled drug delivery systems [74]. The molecule weight (Mw) which affects the cytotoxicity of poly(NIPAM) was examined. The findings indicate that low values of poly(NIPAM) Mw (degree of polymerisation $(D P)=35$ ) are toxic for cells. Mean values of poly(NIPAM) Mw with the DP ranging between 100 and 200 are non-cytotoxic. When cells are disseminated on the top of the polymer surface, poly(NIPAM) with higher $\mathrm{Mw}(\mathrm{DP}=400)$ indicates non/low cytotoxicity, while in the case of single-level cells exposed to a polymer solution, cell viability drops dramatically. This can be the result of the lack of oxygen, rather than an impact of polymers [75]. In the paper of Barnes et al., poly(NIPAM) was used for improving mechanical properties of biological collagen-based hydrogel, while preserving cytological stability [76]. Due to the increasing distribution of bacterial isolates which are no longer sensitive to antibiotics, the emphasis was recently made on finding alternative methods of treating wound infections. Bacteriophage $K$ was successfully formulated with poly(NIPAM) nanospheres which are copolymerized with alilamine, ALA. The use of thermosensitive polymer ensures that nanospheres contract at higher temperature, which is related to bacterial skin infection. Bakteriophage incorporated in poly( $\mathrm{N}$-isopropylacrilamide)-co-alilamine nanosphere proved to be successful in destruction of clinically relevant bacterial isolate-Staphilococcus aureus ST228 at $37^{\circ} \mathrm{C}$ [77]. In order to increase the phase transition temperature to the approximate value of the human body, NIPAM typically copolymerizes with hydrophilic monomers. LCST of the obtained copolymer is approximate to the human body temperature. The change of acrylamide sequence of NIPAM induces low copolymer thermosensitivity. However, copolymerization of NIPAM by monomers which are similar in structure, NIPMAM for example, are ideal alternative to generate a copolymer with a sharp phase transition at the temperature approximate to the one in the human body [16].

\section{Copolymers based on NIPMAM and NIPAM}

The synthesis of copolymers, microgels and nonogels based on NIPAM and NIPMAM can be found in the available literature [16,78-80]. Poly(NIPMAM-co-NIPAM) is a thermosensitive copolymer. It demonstrated a sharp phase transition on the temperature approximate to the one in the human body, given the physiological conditions [16]. The phase transition in poly(NIPMAM-co-NIPAM) copolymers in $\mathrm{D}_{2} \mathrm{O}$ solution depends on the composition of the copolymer itself whereupon the region of the phase transition shifts towards higher temperature with the increase in the NIPMAM content. The phase transition temperature of poly(NIPMAM-co-NIPAM) copolymer synthesized at the molar ratio NIPMAM/NIPAM $1 / 3$ is by $3{ }^{\circ} \mathrm{C}$ higher than in the copolymer obtained at the mole ratio $3 / 1$ [78]. In the paper of Kokufuta et al., LCST of poly(NIPMAM-co-NIPAM) copolymer was examined depending on the composition of the copolymer in water. The findings of the research show that with the increase in the NIPMAM molar fraction in the copolymer, there is a linear increase in LCST from $32{ }^{\circ} \mathrm{C}$ (homopolymer poly(NIPAM)) to $42{ }^{\circ} \mathrm{C}$ (homopolymer poly(NIPMAM)) [80]. The chemical structure of the poly(NIPMAM-coNIPAM) copolymer is presented in Figure 3.

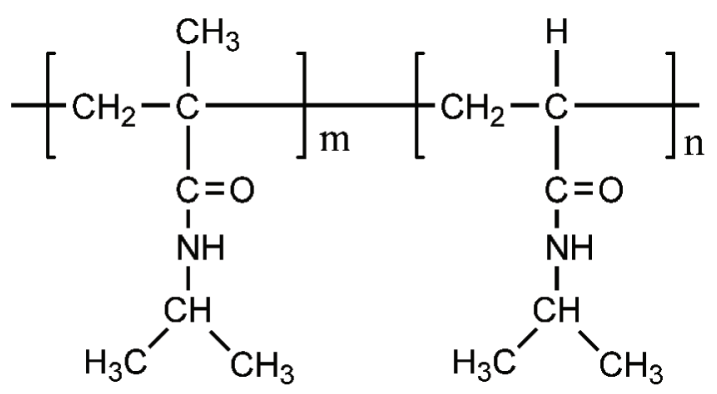

Figure 3. The chemical structure of poly(NIPMAM-co-NIPAM) copolymer

In poly(NIPMAM-co-NIPAM) microgels, LCST rises linearly with the increase in the NIPMAM content in the copolymer. In fact, the values of phase transitions of the copolymer are between the values of LCST in pure poly(NIPAM) and poly(NIPMAM). Poly(NIPMAM-co-NIPAM) copolymer in molar ratio 51/49 shows the LCST value approximate to the human body temperature $\left(36.8^{\circ} \mathrm{C}\right)$, thus making it suitable for biomedical use [16]. Yung and Bae studied the phase transition temperature of the NIPMAM and NIPAM gel in nanometric size. Once again, the findings by these researchers confirm the fact that the increase in the number of methyl groups, i.e. the NIPMAM content in the structure of copolymers causes a higher phase transitions temperature [79]. 
Procedures for synthesizing of NIPMAM and NIPAMbased copolymers

In the paper of Starovoytova et al., NIPMAM and NIPAM monomers were used for synthesizing a random poly(NIPMAM-Co-NIPAM) copolymer through UV polymerization in ethanol at about $5{ }^{\circ} \mathrm{C}$ for $1 \mathrm{~h}$ [78]. Poly(NIPMAM-co-NIPAM) copolymers of different compositions were prepared through free radical polymerization by using $\alpha, \alpha^{\prime}$-azobis(isobutironitrile) (AIBN) as an initiator [80]. Microgels based on NIPMAM and NIPAM were synthesized through radical dispersion [81] and precipitation polymerization [82].

Poly(NIPMAM-co-NIPAM) microgels were synthesized through free radical copolymerization of NIPMAM and NIPAM in the mixture of water and methanol, in the presence of a small quantity of BIS cross-linker in the study of Fundueanu et al. An important condition for microgels is that they must retain their thermosensitive characteristics. The degree of swelling in microgels decreases at the around approximate temperature, and drops sharply above the critical temperature. The volume phase transition temperature (VPTT) value calculated by Boltzman's fitting of experimental data was $33.7^{\circ} \mathrm{C}[16]$ In the study of Yung and Bae poly(NIPMAM-co-NIPAM) nanogels with different molar fraction were synthesized through precipitation polymerization. In order to predict hydrogel swelling, the theory of modified double lattice and Flory-Erman's theory of elasticity were combined [79]. IPN poly(NIPMAM)-co-poly(NIPAM) was examined by Hanyková et al. IPN network was synthesized through swelling of poly(NIPMAM) network in the ethanol solution of NIPAM monomer, in the presence of photoinitiator Darocur 1173 and BIS cross-linker, in the refrigerator without the presence of light and air. On the basis of the research findings, it was concluded that the behavior of IPN depends on the ratio of both components $[51,83]$ Double temperature sensitive core-shell microgels based on poly(NIPMAM) and poly(NIPAM) were synthesized through emulsion polymerization. Berndt et al. have investigated the structural characteristics in detail [84], as well as the impact of the shell thickness and the content of the cross-linker on the structure of the related microgels $[85,86]$.

In the study of Wang et al., poly(NIPAM)-core, poly(NIPMAM)-shell microgels were synthesized through precipitation polymerization and then treated with alkaline bleacher whereupon chloramides were formed, primarily within the microgel core. The research showed that synthesized microgels are coloidally stable after chlorination [87]. In the study of Clark et al., coreshell microgels based on NIPMAM, NIPAM and AA were also synthesized through precipitation polymerization. Microgels were synthesized so that the layers of temperature- and $\mathrm{pH}$-sensitive films were separated, which is one of the methods of synthesis of complex systems [88].

Characterization of NIPMAM and NIPAM-based copolymers By applying ${ }^{1} \mathrm{H}$ NMR spectroscopy it was found that poly(NIPMAM)-co-poly(NIPAM) mixture and poly(NIPMAM-co-NIPAM) copolymer indicate two and one phase transition, respectively [78]. LCST of poly(NIPMAM-Co-NIPAM) copolymer in water was examined by the combination of DSC method and the measurement of turbidity of the solution [80].

IPN poly(NIPMAM)-co-poly(NIPAM) were characterized by the ${ }^{1} \mathrm{H}$ NMR method, DSC method, dynamic mechanical spectroscopy [51,83], optical microscopy [83], SANS [51] in order to determine the IPN contraction inducing temperature $[51,83]$. In order to take advantage of specific properties of hydrogel due to their application in various fields, it is essential that we know their structure. Dynamic light scattering (DLS), optical transition, DSC and SANS are the methods effectively used to examine the structure of macromolecules, as well as core-shell microgels [82,84-86]. The swelling properties of poly(NIPMAM-co-NIPAM) nanohydrogels were examined by photon correlation spectroscopy (PCS) [79].

Application of copolymers based on NIPMAM and NIPAM

Polymers that have the capacity to alter their chemical and physical properties when exposed to various external stimuli [89] such as $\mathrm{pH}$ [90], temperature [91], mechanical force [92], ionic strength, magnetic and electric field are called 'intelligent' or 'smart' polymers. Hydrogels sensitive to environmental changes have immense potential in various applications [93]. These materials have intensively been studied in the past years for their application in the field of biology and medicine [94], controlled [95] and targeted drug delivery [96], environmental protection [97] and many other applications [98-100]. Of all the stimuli mentioned above, the impact of temperature has been studied the most. Due to slight temperature changes, thermosensitive polymers demonstrate significant changes in their structure. Owing to this property, they have a wide range of application [101].

Poly(NIPAM) is the most intensively studied thermosensitive polymer that found its application in drug delivery, cell cultures and tissue engineering. The thermosensitive polymer phase transition is conditioned by: polymer intermolecular interaction, temperature, the presence of functional polymer groups, ionic and hydrophobic interaction and hydrogen bonds [102].

Smart polymer microgels draw considerable attention due to a quick response to the change in stimuli in the environment such as temperature, $\mathrm{pH}$, ionic strength and the presence of some biological molecules. Poly(NIPAM) and their copolymer microgels have been synthesized and characterized for various purposes in the past 10 years. In their study, Begum et al. described the synthesis, basic properties and the application of poly(NIPAMco-AA) microgels in the field of medicine, environmental protection and nanotechnology [103]. In the past decade, thermosensitive hybrid microgels have been used as catalyzators for degradation of toxic chemicals. Recent research, progress in synthesis, characterization and the catalytic application of various hybrid poly(NIPAM)- 
based microgels were described in the study of Farooqui et al. [104].

However, in recent years, the attention of researchers was drawn by another AM derivative, that is, poly(NIPMAM). The temperature range of the phase transition of poly(NIPMAM) microgels is very close to the biologically significant range, which makes them interesting for the potential biological application such as drug delivery [42]. The potential for encapsulating and controlled release is provided by core/shell microgels based on poly(NIPAM) and poly(NIPMAM) due to the fact that the density of shell and core are temperature dependent [84]. Poly(NIPMAM-co-NIPAM) microgels synthesized through free radical polymerization with molar ratio of monomer 51/49 demonstrate a high degree of swelling and contraction at any temperature change below or above VPTT and vice versa. The model substance, dexamethasone, was used for loading synthesized microgels by the method of solution evaporation. Dexamethasone is released by a pulsating mechanism under the temperature change below or above VPTT [16].

The improvement in the properties of various materials enables progress in the pharmaceutical and cosmetic application and protein immobilization [85]. Thermosensitive microgels synthesized from poly(NIPAM)-core and poly(NIPMAM)-shell, by using hydrolythic degredable cross-linker $\mathrm{N}, \mathrm{O}$-dimethacryloyl hydroxylamine, have a potential application as systems for the delivery of the drug substance. After hydrolythic decomposition of the shell, there are some mechanical and chemical changes in microgel, the shell becomes softer and more porous, thus enabling more core swelling. Thermosensitive systems can be applied for local radiotherapy. The systems based on copolymer of NIPMAM and three different types of MAM containing hydrophobic $n$-alkyls of various sizes $\left(C_{3}, C_{6}\right.$ and $\left.C_{12}\right)$ were developed. Alkyle groups for methacrylamide unit are bound with the hydrazone bond which is hydrolythically labile. Upon hydrolythic cleavage of the hydrazone bond, copolymers demonstrate a higher cloud temperature, higher than $44^{\circ} \mathrm{C}$, thus leading to their solubility at the body temperature. Complete solving of polymer synthesized from $27.5 \mathrm{~mol} \%$ comonomer with $\mathrm{C}_{6}$ alkyle residue is achieved within $48 \mathrm{~h}$ on both examined $\mathrm{pH}$ values (5.0 i 7.4). Hydrophobic helate radionuclide ${ }^{64} \mathrm{Cu}$, bis(quinolin-8-olato- $N, O$ ) $\left[{ }^{64} \mathrm{Cu}\right]$ copper, was used as a model substance. The radionuclide complex is efficiently entrapped within the synthesized polymers until their total dissolution through the process of hydrolysis, thus achieving a therapeutic effect.

The release of the drug substance from the copolymer based on NIPMAM and MAM comonomer containing hydrophobic alkyle residues through dissolution due to the hydrolythic cleavage of hydrazone bond is graphically presented in Figure 4 [105].

Ternary copolymer of NIPMAM, N-propyl methacrylamide and 4-nitrophenyl $\mathrm{N}$-methacryloylglycylglycinate in reaction with hydrazine forms a system for delivery of doxorubicine. The drug is connected to the system through $\mathrm{pH}$-sensitive hydrazone bond. At $41^{\circ} \mathrm{C}$, the system undergoes the phase separation in the aqeous solution and releases doxorubicine. The degree of the drug release is higher at $\mathrm{pH} 5$ compared to 7.4. The system proved to be favourable for the delivery of chemotherapeutic agents in the treatment of tumor, due to the prolonged drug release [106].

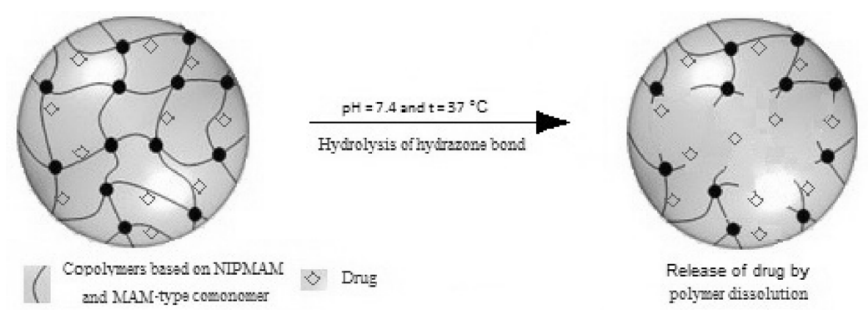

Figure 4. The release of the drug substance from the copolymer based on NIPMAM and MAM comonomer through dissolution due to the hydrolythic cleavage of the hydrazone bond

Bioconjugate of thermosensitive polymer and enzyme of celulase with the recycling capacity was obtained in the study of Ding et al. [107]. First, a copolymer was synthesized through polymerization from methyl acrylate, MA, NIPMAM and $N$-methylolacrylamide, N-MAM, which subsequently carried out bioconjugation with celulase through the process of polymerization, PNMN-C. The enzyme is connected to the synthesized polymer with a covalent bond. Hence, the obtained product demonstrates the LCST of $52.5^{\circ} \mathrm{C}$. Through immobilization on the synthesized copolymer, the celulase enzyme is more stable against the changes in temperature and $\mathrm{pH}$ values compared to the free enzyme. The most important characteristics of bioconjugates of thermosensitive polymer and enzyme is seen in recycling i.e. re-use. After 5 repeated uses a relative activity of bioconjugates is $84.1 \%$.

Poly( $N$-isopropylacrylamide-co-itaconic acid) hydrogel, poly(NIPAM-co-IA), and poly(NIPAM) particles are used for immobilization of lipase enzyme [108,109]. The immobilization of lipase from Candida rugose was carried out by the procedure of poly(NIPAM-co-IA) hydrogel polymerization in the presence of enzyme. The structure of hydrogel has a significant impact on the activities of immobilized enzyme, so that with the increase of IA content, the swelling degree of hydrogel rises and so does the activity of lipase [108]. The lipase enzyme B from Candida antarctica was immobilized on poly(NIPAM) particles of micronic size by changing the polar solvent (isopropanol) with the organic solvent ( $n$-hexan). The lipase enzyme is homogeneously dispersed in the hydrogel matrix. The poly(NIPAM) particles with the immobilized enzyme are stable in $n$-hexane and the relative enzyme activity is $90 \%$ after 6 days. After 4 repeated uses of this system, the specific enzyme activity slightly diminishes [109]. Hydrogels obtained through copolymerization of NIPAM and $\mathrm{N}$-hydroxysuccinimide, and later cross-linked with polylizine can be used as membrane 
immobilization systems for lipide vesicules [110]. Matsumoto et al. developed new glucose-sensitive polymers responsive to physiological conditions $\left(\mathrm{pH} 7.4\right.$ i $\left.37^{\circ} \mathrm{C}\right)$ for the application in the form of a system for a selfregulating insuline injection in the treatment of diabetis melitus. The synthesized derivative of phenylboronic acid (4-(1,6-dioxo-2,5-diaza-7-oxamyl), (DDOPBA) and poly(NIPMAM) were used in the synthesis. The main chain in polymer is poly(NIPMAM) which shows critical behaviour in the solution at the temperature range approximate to the physiological temperature. DDOP$B A$ is a part of structure which is sensitive to glucose and was used for maintaining a low pKa value $(\sim 7.8)$. Poly(NIPMAM) was used instead of poly(NIPAM) for the synthesis of the main chain of the system in order to improve operative temperature conditions. Thus, the temperature interval in which the system is functionally increased, which leads to more expressive sensitivity of the glucose system approximating the physiological temperature [111].

\section{Conclusion}

In the available literature the synthesis of poly(NIPMAM-co-NIPAM) hydrogels of micrometric and nanometric sizes was described. This study provides a description of various processes of IPN poly(NIPMAM)co-poly(NIPAM) synthesis, as well as the synthesis of poly(NIPMAM-Co-NIPAM) copolymers. The related types of polymer materials were synthesized through precipitation, emulsion, free radical and UV polymerization. By applying the method of dynamic light scattering, optical transition, ${ }^{1} \mathrm{H}$ NMR spectroscopy, differential scanning calorimetry, small angle neutron scattering and dynamic light scattering, the obtained polymer materials were effectively characterized. Due to NIPMAM and NIPAM copolymerization, the phase transition occurs at the temperature which is approximate to the physiological temperature of the human body $\left(36.8^{\circ} \mathrm{C}\right)$ and ranges within the phase transition temperature of poly(NIPAM) and poly(NIPMAM), thus making these systems usable in a controlled drug delivery, protein immobilization and in biomedicine.

Further research should be focused on the synthesis of thermosensitive poly(NIPMAM-co-NIPAM) hydrogels with a different molar ratio of monomers, the characterization of obtained products, as well as the identification of new prospects of use.

\section{Acknowledgements}

This work is part of the project MNTR TR-34012 financed by the Ministry of Education, Science and Technological Development of the Republic of Serbia. The authors are grateful for the support provided by the Ministry.

\section{Abbreviations and symbols}

Poly( $N$-isopropylmethacrylamide), poly(NIPMAM)

Poly( $N$-isopropylacrylamide), poly(NIPAM)

$\mathrm{N}$-isopropylmethacrylamide, (NIPMAM)

$\mathrm{N}$-isopropylacrylamide, (NIPAM)

Low critical solution temperature, (LCST)

Poly $(N$-isopropylmethacrylamide-co- $N$-isopropylacryla

mide), poly(NIPMAM-co-NIPAM)

Poly(N-vynylcaprolactam), poly(VCL)

Nuclear magnetic resonance, (NMR)

Differential scanning calometry, (DSC)

Acrylamide, (AM)

Metacrylamide, (MAM)

Attenuated total reflection-Fourier transform infrared spec troscopy, (ATR-FTIR)

Poly(N-n-propyl acrylamide), poly(NNPAM)

Scanning electronic microscopy, (SEM)

Atomic force microscopy, (AFM)

Sodium dodecyl sulfate, (SDS)

Cetyl trimetylammonium bromide, (CTAB)

Critical miscelle concentration, (CMC)

Poly(acrylic acid), poly(AA)

Poly(methacrylic acid), poly(MAA)

$N, N^{\prime}$-methylenebisacrylamide, (BIS)

Poly( $\mathrm{N}$-isopropylacrylamide-co-2-hydroxypropyl meth

acrylate), poly(NIPAM-co-HPMet)

Poly( $N$-isopropylacrylamide-co-acrylic acid), poly(NIPAMco-AA)

Poly(diallyldimethylammonium chloride), poly(DADMAC)

Polyethylene glycol, (PEG)

Potassium persulfate, (KPS)

Phosphotungstic acid, (PTA)

Upper critical solution temperature, (UCST)

Interpenetrating polymer networks, (IPN)

Double network, (DN)

Nanocomposites, (NC)

Small angle neutron scattering, (SANS)

Sodium alginate-graft-poly( $N$-isopropylacrylamide) (SA-gpoly(NIPAM))

Molecule weight, (Mw)

Degree of polymerisation, (DP)

Alilamine, (ALA)

$\alpha, \alpha^{\prime}$-azobis(isobutironitrile), (AIBN)

Dynamic light scattering, (DLS)

Photon correlation spectroscopy, (PCS)

Methyl acrylate, (MA)

$N$-methylolacrylamide, (N-MAM)

Poly(N-isopropylacrylamide-co-itaconic acid), poly(NIPAMCO-IA)

Phenylboronic acid (4-(1,6-dioxo-2,5-diaza-7-oxamyl), (DDOPBA)

\section{References}

[1] E. Caló, V. V. Khutoryanskiy, Biomedical applications of hydrogels: A review of patents and commercial products, European Polymer Journal, 65 (2015) 252-267.

[2] N. A. Peppas, P. Bures, W. Leobandung, H. Ichikawa, Hydrogels in pharmaceutical formulations, European Journal of Pharmaceutics and Biopharmaceutics, 50(1) (2000) 27-46.

[3] S. Ilić-Stojanović, L. Nikolić, V. Nikolić, S. Petrović, M. Stanković, I. Mladenović-Ranisavljević, Stimuli-sensitive 
hydrogels for pharmaceutical and medical applications, Facta Universitatis-Physics, Chemistry and Technology, 9(1) (2011) 37-56.

[4] S. C. Lee, I. K. Kwon, K. Park, Hydrogels for delivery of bioactive agents: A historical perspective, Advanced Drug Delivery Reviews, 65 (2013) 17-20.

[5] F. Ullah, M. B. H. Othman, F. Javed, Z. Ahmad, H. M. Akil, Classification, processing and application of hydrogels: A review, Materials Science and Engineering C, 57 (2015) 414-433.

[6] M. C. Koetting, J. T. Peters, S. D. Steichen, N. A. Peppas, Stimulus-responsive hydrogels: Theory, modern advances, and applications, Materials Science and Engineering R, 93 (2015) 1-49.

[7] A. S. Hoffman, Hydrogels for biomedical applications. Advanced Drug Delivery Reviews, 43 (2002) 3-12.

[8] S. Ilić-Stojanović, L. Nikolić, V. Nikolić, I. Ristić, J. Budinski-Simendić, A. Kapor, G. M. Nikolić, The structure characterisation of thermosensitive poly $(N$ isopropylacrylamide-co-2-hydroxypropyl methacrylate) hydrogel, Polymer International, 63(6) (2014) 973-981.

[9] S. Ilić-Stojanović, Synthesis and characterization of negatively thermosensitive hydrogels, LAP LAMBERT Academic Publishing, Akademikeverlag GmbH \& Co. KG, Saarbrücken, Germany, 2015, p. 80.

[10] M. R. Matanović, J. Kristl, P.A. Grabnar, Thermoresponsive polymers: Insights into decisive hydrogel characteristics, mechanisms of gelation, and promising biomedical applications, International Journal of Pharmaceutics, 472 (2014) 262-275.

[11] A. Gandhi, A. Paul, S. O. Sen, K. K. Sen, Studies on thermoresponsive polymers: Phase behaviour, drug delivery and biomedical applications, Asian Journal of Pharmaceutical Sciences, 10(2) (2015) 99-107.

[12] L. Klouda, Thermoresponsive hydrogels in biomedical applications A seven-year update, European Journal of Pharmaceutics and Biopharmaceutics, 97 (2015) 338349.

[13] L. Klouda, A. G. Mikos, Thermoresponsive hydrogels in biomedical applications, European Journal of Pharmaceutics and Biopharmaceutics, 68 (2008) 34-45.

[14] R. Dinarvand,A. D'Emanuele, The use of thermoresponsive hydrogels for on-off release of molecules, Journal of Controlled Release, 36(3) (1995) 221-227.

[15] S. Purushotham, R. V. Ramanujan, Thermoresponsive magnetic composite nanomaterials for multimodal cancer therapy, Acta Biomaterialia, 6 (2010) 502-510.

[16] G. Fundueanu, M. Constantin, S. Bucatariu, P. Ascenzi, Poly $(N$-isopropylacrylamide-co- $N$ isopropylmethacrylamide) Thermo-Responsive Microgels as Self-Regulated Drug Delivery System, Macromolecular Chemistry and Physics, 217 (2016) 2525-2533.

[17] J. Spěváček, NMR investigations of phase transition in aqueous polymer solutions and gels, Current Opinion in Colloid and Interface Science, 14 (2009) 184-191.

[18] X. Hu, Z. Tong, A. Lyon, One-Pot Synthesis of Microcapsules with Nanoscale Inclusions, Macromolecular Rapid Communications, 32 (2011) 1461-1466.

[19] J. Spěváček, J. Dybal, Stimuli-Responsive Polymers in Solution Investigated by NMR and Infrared Spectroscopy, Macromolecular Symposia, 303 (2011) 17-25.

[20] Y. Tang, Y. Ding, G. Zhang, Role of Methyl in the Phase Transition of Poly( $\mathrm{N}$-isopropylmethacrylamide), Journal of Physical Chemistry B, 112(29) (2008) 8447-8451.
[21] Y. Tang, X. Liu, Collapse kinetics for individual poly $(N$ isopropylmethacrylamide) chains, Polymer, 51 (2010) 897-901.

[22] E. Djokpe, W. Vogt, N-Isopropylacrylamide and $\mathrm{N}$-Isopropylmethacrylamide:Cloud Points of Mixtures and Copolymers, Macromolecular Chemistry and Physics, 202 (2001) 750-757.

[23] M. Netopilik, M. Bohdanecky, V. Chytry, K. Ulbrich, Cloud point of poly( $N$-isopropylmethacrylamide) solutions in water: is it really a point?, Macromolecular Rapid Communications, 18 (1997) 107-111.

[24] L. P. Zhang, I. Noda, Y. Wu, An application of concatenated 2D correlation spectroscopy: Exploration of the reversibility of the temperature-induced hydration variation of poly $(N-$ isopropylmethacrylamide) in aqueous solution, Journal of Molecular Structure, 974 (2010) 80-87.

[25] L. P. Wu, I. Noda, Y. Wu, Quantitative comparison of reversibility in thermal-induced hydration of $\operatorname{poly}(\mathrm{N}$-isopropylacrylamide $)$ and $\operatorname{poly}(N$ isopropylmethacrylamide) in aqueous solutions by "concatenated" 2D correlation analysis, Vibrational Spectroscopy, 60 (2012) 200-205.

[26] Y. E. Kirsh, N. A. Yanul, Y. M. Popkov, Temperature behavior of thermo-responsive poly- $\mathrm{N}$-vinylcaprolactam and poly- $\mathrm{N}$-isopropylmethacrylamide in aqueous solutions involving organic solutes, European Polymer Journal, 38(2) (2002) 403-406.

[27] H. Kouřilová, J. Spěváček, L. Hanyková, 1H NMR study of temperature-induced phase transitions in aqueous solutions of poly( $N$-isopropylmethacrylamide $) / \operatorname{poly}(N$ vinylcaprolactam) mixtures, Polymer Bulletin, 70 (2013) 221-235.

[28] L. Starovoytova, J. Spěvaček, Effect of time on the hydration and temperature-induced phase separation in aqueous polymer solutions. ${ }^{1} \mathrm{H}$ NMR study, Polymer, 47 (2006) 7329-7334.

[29] H. Kouřilová, J. Št’astná, L. Hanyková, Z. Sedláková, J. Spěváček, ${ }^{1} \mathrm{H}$ NMR study of temperature-induced phase separation in solutions of poly $(\mathrm{N}$-isopropylmethacrylamideco-acrylamide) copolymers, European Polymer Journal, 46 (2010) 1299-1306.

[30] L. Starovoytova, J. Spěvaček, M. Trchová, ${ }^{1} H$ NMR and IR study of temperature-induced phase transition of negatively charged poly( $N$-isopropylmethacrylamide-cosodium methacrylate) copolymers in aqueous solutions, European Polymer Journal, 43 (2007) 5001-5009.

[31] J. Št’astná, L. Hanyková, J. Spěváček, NMR and DSC study of temperature-induced phase transition in aqueous solutions of poly $(N$-isopropylmethacrylamideco-acrylamide) copolymers, Colloid and Polymer Science, 290 (2012) 1811-1817.

[32] H. Kouřilová, L. Hanyková, J. Spěváček, NMR study of phase separation in $\mathrm{D}_{2} \mathrm{O}$ /ethanol solutions of $\operatorname{poly}(\mathrm{N}$ isopropylmethacrylamide) induced by solvent composition and temperature, European Polymer Journal, 45 (2009) 2935-2941.

[33] J. Spěvaček, Phase separation in aqueous polymer solutions as studied by NMR methods, Macromolecular Symposia, 222 (2005)1-13.

[34] J. Spěvaček, Structures and Interactions in Polymer Systems Characterized by NMR Methods, The Open Macromolecules Journal, 4 (2010) 22-25.

[35] M. Salmerón Sánchez, L. Hanyková, M. Ilavský, M. Monleón Pradas, Thermal transitions of $\operatorname{poly}(N-$ 
isopropylmethacrylamide) in aqueous solutions, Polymer, 45 (2004) 4087-4094.

[36] S. Habaue, Y. Isobe, Y. Okamoto, Stereocontrolled radical polymerization of acrylamides and methacrylamides using Lewis acids, Tetrahedron, 58 (2002) 8205-8209.

[37] J. Dybal, M. Trchová, P. Schmidt, The role of water in structural changes of poly( $\mathrm{N}$-isopropylacrylamide) and poly(N-isopropylmethacrylamide) studied by FTIR, Raman spectroscopy and quantum chemical calculations, Vibrational Spectroscopy, 51 (2009) 44-51,

[38] E. I. Tiktopulo, V. N. Uversky, V. B. Lushchik, S. I. Klenin, V. E. Bychkova, O. B. Ptitsyn, Domain coile globule transition in homopolymers, Macromolecules, 28 (1995) 7519-7524.

[39] K. Kubota, K. Hamano, N. Kuwahara, S. Fujishige, I. Ando, Characterization of poly( $\mathrm{N}$-isopropylmethacrylamide) in water, Polymer Journal, 22 (1990) 1051-1057.

[40] A. D. Drozdov, C.-G. Sanporean, J. deC. Christiansen, Modeling the effects of temperature and $\mathrm{pH}$ on swelling of stimuli-responsive gels, European Polymer Journal, 73 (2015) 278-296.

[41] B. Wedel, Y. Hertle, O. Wrede, J. Bookhold, T. Hellweg, Smart Homopolymer Microgels: Influence of the Monomer Structure on the Particle Properties, Polymers, 8(4) (2016) $1-21$.

[42] V. K. Nessen, M. Karg, T. Hellweg, Thermoresponsive poly(N-isopropylmethacrylamide) microgels:Tailoring particle size by interfacial tension control, Polymer, 54 (2013) 5499-5510.

[43] D. Duracher, A. Elaïssari, C. Pichot, Characterization of cross-linked poly(N-isopropylmethacrylamide) microgel latexes, Colloid and Polymer Science, 277 (1999) 905913.

[44] I. Alenichev, Z. Sedláková, M. Ilavský, Swelling and mechanical behavior of charged poly $(\mathrm{N}$ isopropylmethacrylamide) and poly $(\mathrm{N}$ isopropylacrylamide) networks in water/ethanol mixtures. Cononsolvency effect, Polymer Bulletin, 58 (2007) 191199.

[45] L. Ruiz-Rubio, V. Álvarez, E. Lizundia, J. L. Vilas, M. Rodríguez, L. M. León, Influence of a-methyl substitutions on interpolymer complexes formation between poly(meth) acrylic acids and poly( $\mathrm{N}$-isopropyl(meth)acrylamide)s, Colloid and Polymer Science, 293 (2015) 1447-1455.

[46] S. Fujishige, K. Kubota, I. Ando, Phase Transition of Aqueous Solutions of Poly(N-isopropylacrylamide) and Poly(N-isopropylmethacrylamide), The Journal of Physical Chemistry, 93(8) (1989) 3311-3313.

[47] H. G. Schild, Poly(N-isopropylacrylamide): experiment, theory and application, Progress in Polymer Science, 17(2) (1992) 163-249.

[48] V. O. Aseyev, H. Tenhu, F. M. Winnik, Temperature dependence of the colloidal stability of neutral amphiphilic polymers in water, Advances in Polymer Science, 196 (2006) 1-85.

[49] S. C. Lee. J. Y. Chang, Thermosensitive Block Copolymers Consisting of Poly(N-isopropylacrylamide) and Star Shape Oligo(ethylene oxide), Bulletin of the Korean Chemical Society, 30(7) (2009) 1521-1525.

[50] X. S. Wu, A. S. Hoffman, P. Yager, Synthesis and characterization of thermally reversible macroporous poly(N-isopropylacrylamide) hydrogels, Journal of Polymer Science Part A: Polymer Chemistry, 30(10) (1992) 2121-2129.
[51] L. Hanyková, J. Spěváček, M. Radecki, A. Zhigunov, J. Št’astná, H. Valentová, Z. Sedláková, Structures and interactions in collapsed hydrogels of thermoresponsive interpenetrating polymer networks, Colloid and Polymer Science, 293 (2015) 709-720.

[52] Y. Zhang, J. Cal, C. Li, J. Wei, Z. Liu, W. Xue, Effects of thermosensitive poly( $\mathrm{N}$-isopropylacrylamide) on blood coagulation, Journal of Materials Chemistry B, 4 (2016) 3733-3749.

[53] M. Heskins, J. E. Guillet, Solution Properties of Poly(Nisopropylacrylamide). Journal of Macromolecular Science, Part A: Pure and Applied Chemistry, 2(8) (1968) 14411455.

[54] M. Kurečič, M. Sfiligoj-Smole, K. Stana-Kleinschek, Uv polymerization of poly( $\mathrm{N}$-isopropylacrylamide) hydrogel, Materials and Technology, 46(1) (2012) 87-91.

[55] B. H. Cipriano, S. J. Banik, R. Sharma, D. Rumore, W. Hwang, R. M. Briber, S. R. Raghavan, Superabsorbent Hydrogels That Are Robust and Highly Stretchable, Macromolecules, 47(13) (2014) 4445-4452.

[56] A. S. Zdravković, L. B. Nikolić, S. S. Ilić-Stojanović, V. D. Nikolić, S. R. Savić, A. J. Kapor, The evaluation of temperature and $\mathrm{pH}$ influences on equilibrium swelling of poly(N-isopropylacrylamide-co-acrylic acid) hydrogels, Chemical Industry (2017) In Press DOI:10.2298/ HEMIND161018001Z.

[57] W. Cai, E. C. Anderson, R. B. Gupta, Separation of Lignin from Aqueous Mixtures by Ionic and Nonionic Temperature-Sensitive Hydrogels, Industrial and Engineering Chemistry Research, 40(10) (2001) 22832288.

[58] X. Xie, J. Bahnemann, S. Wang, Y. Yang, M. R. Hoffmann, "Nanofiltration" Enabled by Super- Absorbent Polymer Beads for Concentrating Microorganisms in Water Samples, Scientific Reports, 6 (2016) 20516.

[59] H. L. Abd El-Mohdy, Water sorption behavior of CMC/ PAM hydrogels prepared by $\mathrm{y}$-irradiation and release of potassium nitrate as agrochemical, Reactive and Functional Polymers, 67(10) (2007) 1094-1102.

[60] B. Singh, D. K. Sharma, A. Gupta, In vitro release dynamics of thiram fungicide from starch and poly(methacrylic acid)based hydrogels, Journal of Hazardous Materials, 154(13) (2008) 278-286.

[61] W. E. Rudzinski, A. M. Dave, U. H. Vaishnav, S. G. Kumbar, A. R. Kulkarni, T. M. Aminabhavi, Hydrogels as controlled release devices in agriculture, Designed Monomers and Polymers, 5(1) (2002) 39-65.

[62] M. R. Islam, S. Xie, D. Huang, K. Smyth, M. J. Serpe, Poly(N-Isopropylacrylamide) mikrogel-based optical devices for humidity sensing, Analytica Chimica Acta, 898 (2015) 101-108.

[63] X. J. Ju, S. B. Zhang, M. Y. Zhou, R. Xie, L. Yang, L. Y. Chu, Novel heavy-metal adsorption material: ion-recognition P(NIPAM-co-BCAm) hydrogels for removal of lead(II) ions, Journal of Hazardous Materials, 167(1-3) (2009) 114-118.

[64] J. Cheng, G. Shan, P. Pan, Temperature and pHdependent swelling and copper(II) adsorption of poly(Nisopropylacrylamide) copolymer hydrogel, RSC Advances, 5(76) (2015) 62091-62100.

[65] J. J. Chen, A. L. Ahmad, B. S. Ooi, Thermo-responsive properties of poly(N-isopropylacrylamide-co-acrylic acid) hydrogel and its effect on copper ion removal and fouling of polymer-enhanced ultrafiltration, Journal of Membrane Science, 469 (2014) 73-79. 
[66] P. Guo, H. Li, W. Ren, J. Zhu, F. Xiao, S. Xu, J. Wang, Unusual thermo-responsive behaviors of poly(NIPAMco-AM)/PEG/PTA composite hydrogels, Materials Letters, 143 (2015) 24-26.

[67] M. A. Haq, Y. Su, Y. Wang, Mechanical properties of PNIPAM based hydrogels: A review, Materials Science and Engineering C, 70(1) (2017) 842-855.

[68] M. Radecki, J. Spěváček, A. Zhigunov, Z. Sedláková, L. Hanyková,Temperature-induced phase transition in hydrogels of interpenetrating networks of $\operatorname{poly}(\mathrm{N}$ isopropylacrylamide) and polyacrylamide, European Polymer Journal, 68 (2015) 68-79.

[69] L. Liu, J. Zeng, X. Zhao, K. Tian, P. Liu, Independent temperature and $\mathrm{pH}$ dual-responsive PMAA/PNIPAM microgels as drug delivery system: Effect of swelling behavior of thecore and shell materials in fabrication process, Colloids and Surfaces A: Physicochemical and Engineering Aspects, (2016) In Press DOI:10.1016/j. colsurfa.2016.11.007.

[70] H. Tokuyama, A. Katsuno, I.W. Lenggoro, R. Kanazawa, Preparation of poly( $N$-isopropylacrylamide) hydrogel beads by sedimentation polymerization combined with electrostatic atomization, Polymer Bulletin, 72 (2015) 1603-1610.

[71] K. Palomino K. A. Suarez-Meraz, A. Serrano-Medina, A. Olivas, E. C. Samano, J. M. Cornejo-Bravo, Microstructured poly( $\mathrm{N}$-isopropylacrylamide) hydrogels with fast temperature response for pulsatile drug delivery, Journal of Polymer Research, 22 (2015) 199.

[72] E. Manek, A. Domján, J. Madarász, K. László, Interactions in aromatic probe molecule loaded poly $(\mathrm{N}$ isopropylacrylamide) hydrogels and implications for drug delivery, European Polymer Journal, 68 (2015) 657-664.

[73] M. Constantin, S. Bucatariu, V. Harabagiu, I. Popescu, P. Ascenzi, G. Fundueanu, Poly(N-isopropylacrylamide-comethacrylic acid) $\mathrm{pH} /$ thermo-responsive porous hydrogels as self-regulated drug delivery system, European Journal of Pharmaceutical Sciences, 62 (2014) 86-95.

[74] N. Yu, G. Li, Y. Gao, H. Jiang, Q. Tao, Thermo-sensitive complex micelles from sodium alginate-graft-poly $(N$ isopropylacrylamide) for drug release, International Journal of Biological Macromolecules, 86 (2016) 296-301.

[75] A. Mellati, M. Valizadeh Kiamahalleh, S. Dai, J. Bi, B. Jin, $\mathrm{H}$. Zhang, Influence of polymer molecular weight on the in vitro cytotoxicity of poly( $N$-isopropylacrylamide), Materials Science and Engineering C, 59 (2016) 509-513.

[76] A. L. Barnes, P. G. Genever, S. Rimmer, M. C. Coles, Collagen-Poly( $\mathrm{N}$-isopropylacrylamide) Hydrogels with Tunable Properties, Biomacromolecules, 17(3) (2016) 723-734.

[77] H. Hathaway, D. R. Alves, J. Bean, P. P. Esteban, K. Ouadi, J. M. Sutton, A. T. A. Jenkins, Poly $(N$-isopropylacrylamideco-allylamine), (PNIPAM-co-ALA) nanospheres for the thermally triggered release of Bacteriophage $\mathrm{K}$, European Journal of Pharmaceutics and Biopharmaceutics, 96 (2015) 437-441.

[78] L. Starovoytova, J. Spěvaček, M. Ilavský, ${ }^{1} H$ NMR study of temperature-induced phase transitions in $\mathrm{D}_{2} \mathrm{O}$ solutions of poly $(N$-isopropylmethacrylamide $) / p o l y(N$ isopropylacrylamide) mixtures and random copolymers, Polymer, 46 (2005) 677-683.

[79] S. C. Jung, Y. C. Bae, The effects of interaction energy on the volume phase transition of $\mathrm{N}$-isopropylacrylamideco- $N$-isopropylmethacrylamide nano-sized gel particles:
Applicability of molecular simulation technique, Polymer 50 (2009) 4957-4963.

[80] M. K. Kokufuta, S. Sato, E. Kokufuta, LCST behavior of copolymers of $\mathrm{N}$-isopropylacrylamide and $\mathrm{N}$-isopropylmethacrylamide in water, Colloid and Polymer Science, 290(16) (2012) 1671-1681.

[81] M. Keerl, J. S. Pedersen, W. Richtering, Temperature Sensitive Copolymer Microgels with Nanophase Separated Structure, Journal American Chemical Society, 131 (2009) 3093-3097.

[82] K. C. Clarke, L. A. Lyon, Modulation of the Deswelling Temperature of Thermoresponsive Microgel Films, Langmuir, 29 (2013) 12852-12857.

[83] J. Št’astná, L. Hanyková, Z. Sedláková, H. Valentová, J. Spěváček, Temperature-induced phase transition in hydrogels of interpenetrating networks poly $(N-$ isopropylmethacrylamide)/poly( $N$-isopropylacrylamide), Colloid and Polymer Science, 291 (2013) 2409-2417.

[84] I. Berndt, J. S. Pedersen, P. Lindner, W. Richtering, Structure of Doubly Temperature Sensitive Core-Shell Microgels Based on Poly- $N$-Isopropylacrylamide and Poly-N-Isopropylmethacrylamide, Progress in Colloid and Polymer Science, 133 (2006) 35-40.

[85] I. Berndt, W. Richtering, Doubly Temperature Sensitive Core-Shell Microgels, Macromolecules, 36 (2003) 87808785.

[86] I. Berndt, J. S. Pedersen, P. Lindner, W. Richtering, Influence of Shell Thickness and Cross-Link Density on the Structure of Temperature-Sensitive Poly- $N$ Isopropylacrylamide-Poly- $N$-Isopropylmethacrylamide Core-Shell Microgels Investigated by Small-Angle Neutron Scattering, Langmuir, 22 (2006) 459-468.

[87] Z. Wang, E. Hart, R. Pelton, Hypochlorite activated poly( $N$ isopropylacrylamide)-core poly( $\mathrm{N}$-isopropylmethacrylamide)shell microgels-An oxidant with the potential to kill cells, Colloids and Surfaces A: Physicochemical and Engineering Aspects, 457 (2014) 340-344.

[88] K. C. Clarke, S. N. Dunham, L. A. Lyon, Core/ Shell Microgels Decouple the $\mathrm{pH}$ and Temperature Responsivities of Microgel Films, Chemistry of Materials, 27(4) (2015) 1391-1396.

[89] M. Wei, Y. Gao, X. Li, M. J. Serpe, Stimuli-responsive polymers and their applications, Polymer Chemistry, 8(1) (2017) 127-143.

[90] S. Bazban-Shotorban, M. M. Hasani-Sadrabadi, A. Karkhaneh, A. Serpooshan, K. I. Jacob, A. Moshaverinia, M. Mahmoudi, Revisiting structure-property relationship of $\mathrm{pH}$-responsive polymers for drug delivery applications, Journal of Controlled Release 253 (2017) 46-63.

[91] G. Fundueanu, M. Constantin, S. Bucatariu, P. Ascenzi, $\mathrm{pH} /$ thermo-responsive poly( $\mathrm{N}$-isopropylacrylamide-comaleic acid) hydrogel with a sensor and an actuator for biomedical applications, Polymer, 110 (2017) 177-186.

[92] M. Griffin, L. Nayyer, P. E. Butler, R. G. Palgrave, A. M. Seifalian, D. M. Kalaskar, Development of mechanoresponsive polymeric scaffolds using functionalized silica nano-fillers for the control of cellular functions, Nanomedicine, 12 (2016) 1725-1733.

[93] Y. Qiu, K. Park, Environment-sensitive hydrogels for drug delivery, Advanced Drug Delivery Reviews, 64 (2012) 4960.

[94] J. Hu, S. Liu, Responsive Polymers for Detection and Sensing Applications: Current Status and Future Developments, Macromolecules, 43 (2010) 8315-8330. 
[95] A. K. Bajpai, S. K. Shukla, S. Bhanu, S. Kankane, Responsive polymers in controlled drug delivery, Progress in Polymer Science, 33 (2008) 1088-1118.

[96] B. Tian, S. Liu, S. Wu, W. Lu, D. Wang, L. Jin, B. Hu, K. Li, Z. Wang, Z. Quan, pH-responsive poly (acrylic acid)gated mesoporous silica and its application in oral colon targeted drug delivery for doxorubicin, Colloids and Surfaces B: Biointerfaces, 154 (2017) 287-296.

[97] Y. H. F. Al-qudah, G. A. Mahmoud, M. A. A. Khalek, Radiation crosslinked poly (vinyl alcohol)/acrylic acid copolymer for removal of heavy metal ions from aqueous solutions, Journal of Radiation Research and Applied Sciences, 7 (2014) 135-145.

[98] J. Raczkowska, Y. Stetsyshyn, K. Awsiuk, M. Lekka, M. Marzec, K. Harhay, K. Ohar, D. Ostapiv, M. Sharan, I. Yaremchuk, Y. Bodnar, A. Budkowski, Temperatureresponsive grafted polymer brushes obtained from renewable sources with potential application as substrates for tissue engineering, Applied Surface Science, 407 (2017) 546-554.

[99] A. S. Hoffman, Stimuli-responsive polymers: Biomedical applications and challenges for clinical translation, Advanced Drug Delivery Reviews, 65 (2013) 10-16.

[100] F. Wang, Y. H. Lai, M. Y. Han, Stimuli-Responsive Conjugated Copolymers Having Electro-Active Azulene and Bithiophene Units in the Polymer Skeleton: Effect of Protonation and p-Doping on Conducting Properties, Macromolecules, 37 (2007) 3222-3230.

[101] A. Gandhi, A. Paul, S. O. Sen, K. K. Sen, Studies on thermoresponsive polymers: Phase behaviour, drug delivery and biomedical applications, Asian Journal of Pharmaceutical Sciences, 10 (2015) 99-107.

[102] S. Ashraf, H. K. Park, H. Park, S. H. Lee, Snapshot of phase transition in thermoresponsive hydrogel PNIPAM: Role in drug delivery and tissue engineering, Macromolecular Research, 24(4) (2016) 297-304.

[103] R. Begum, Z. H. Farooqi, S. R. Khan, Poly(Nisopropylacrylamide-acrylic acid) copolymer microgels for various applications: A review, International Journal of Polymeric Materials and Polymeric Biomaterials, 65(16) (2016) 841-852.

[104] Z. H. Farooqi, S. R. Khan, R. Begum, Temperatureresponsive hybrid microgels for catalytic applications: a review, Materials Science and Technology, 33(2) (2017) 129-137.

[105] M. Hruby, J. Kucka , O. Lebeda, H. Mackova, M. Babic, C. Konak, M. Studenovsky, A. Sikora, J. Kozempel, K. Ulbrich, New bioerodable thermoresponsive polymers for possible radiotherapeutic applications, Journal of Controlled Release, 119 (2007) 25-33.

[106] V. Chytry, K. Ulbrich, Conjugate of Doxorubicin with a Thermosensitive Polymer Drug Carrier 16 (2001) 427-440.

[107] Z. Ding, X. Zheng, S. Li, X. Cao, Immobilization of cellulase onto a recyclable thermo-responsivepolymer as bioconjugate, Journal of Molecular Catalysis B: Enzymatic, 128 (2016) 39-45.

[108] N. Milašinović, N. Milosavljević, J. Filipovic, Z. Knežević Jugović, M. Kalagasidis Krušic, Synthesis, characterization and application of poly( $N$-isopropylacrylamide-co-itaconic acid) hydrogels as supports for lipase immobilization, Reactive and Functional Polymers, 70 (2010) 807-814.

[109] K. Gawlitza, C. Wu, R. Georgieva, D. Wang, M. B. Ansorge-Schumacherb, R. von Klitzing, Immobilization of lipase $B$ within micron-sized poly- $N$-isopropylacrylamide hydrogel particles by solvent exchange, Physical Chemistry Chemical Physics, 14 (2012) 9594-9600.

[110] A. Percot, M. Lafleur, X. X. Zhu, New hydrogels based on $\mathrm{N}$-isopropylacrylamide copolymers crosslinked with polylysine: membrane immobilization systems, Polymer, 41 (2000) 7231-7239.

[111] A. Matsumoto, S. Ikeda, A. Harada, K. Kataoka, Glucose-Responsive Polymer Bearing a Novel Phenylborate Derivative as a Glucose-Sensing Moiety Operating at Physiological pH Conditions, Biomacromolecules, 4 (2003) 1410-1416. 
Izvod

\section{HIDROGELOVI NA BAZI N-IZOPROPILMETAKRILAMIDA I N-IZOPROPILAKRILAMIDA}

Maja Z. Urošević ${ }^{1}$, Ljubiša B. Nikolić ${ }^{1}$, Snežana S. Ilić-Stojanović ${ }^{1}$, Vesna D. Nikolić1, Sanja M. Petrović ${ }^{1}$, Aleksandar S. Zdravković

(PREGLEDNI RAD)

UDK 544.773.432:678.7:615.015.3

1 Univerzitet u Nišu, Tehnološki fakultet, Leskovac, Srbija

${ }^{2}$ Visoka tehnološko umetnička strukovna škola, Leskovac, Srbija

Hidrogelovi su trodimenzionalne polimerne mreže koje su u stanju da zadrže veliku količinu vode ili biološke tečnosti u nabubrelom stanju. Posebno interesovanje istraživača postoji za termoosetljive hidrogelove, jer je to parametar koji se najčešće menja u hemijskim, biološkim i fiziološkim sistemima. Termoosetljivi hidrogelovi poseduju kritičnu temperaturu rastvora tj. pokazuju značajnu promenu zapremine sa promenom temperature. Homopolimeri poli $(N$-izopropilmetakrilamida) (poli(NIPMAM)) i poli(N-izopropilakrilamida) (poli(NIPAM)), su termoosetljivi materijali koji su intezivno proučavani poslednjih godina. Monomer NIPMAM se kopolimerizuje sa monomerom NIPAM-a u cilju dobijanja sistema sa temperaturom faznog prelaza približno temperaturi ljudskog tela. U literaturnim podacima dostupna je sinteza i karakterizacija mikrogelova, nanogelova i kopolimera na bazi NIPMAM-a i NIPAM-a. Ovi termoosetljivi polimerni materijali imaju primenu za kontrolisanu isporuku leka i imobilizaciju proteina.
Ključne reči: hidrogelovi, termoosetljivost, $N$-izopropilakrilamid, $N$-izopropilmetakrilamid, sinteza 